\title{
Recovery of leafy spurge seed from sheep
}

\author{
BRET E. OLSON, ROSEANN T. WALLANDER, AND RODNEY W. KOTT
}

Authors are associate professor, research associate, and extension sheep specialist, Department of Animal and Range Sciences, Montana State University, Bozeman, Mont. 59717.

\begin{abstract}
Sheep are often used to graze North American rangelands infested with leafy spurge (Euphorbia esula L.), a long-lived perennial forb from Eurasia. Our objective was to determine if sheep grazing infested rangelands disperse leafy spurge seed by transport in their fleece or by depositing seeds in their feces. Twenty-four yearling Targhee ewes grazed a 2.4 ha native bunchgrass range site infested with leafy spurge from late-May through mid-August of 1993 and 1994. Six of the 24 ewes were shorn in October 1993. To recover leafy spurge seeds from those fleeces, we used a standard method to test wool for vegetable matter. On average, 38 seeds were recovered per fleece. During these summers, 6 small groups ( $n=4$ sheep per group) each grazed 3 separate paddocks. We estimated the density of leafy spurge seed before the groups were moved into 1 of 3 paddocks. After the sheep were moved into a paddock (day 0 ), we collected fresh feces from each group on or about day 4,10 , and 14 . Feces were then washed over sieves to recover leafy spurge seeds. All seeds were tested for germinability and viability. The number of viable seeds excreted daily per ewe was estimated. In 1993, 1,796 \pm 405 (S.E.) leafy spurge seeds $\mathrm{m}^{-2}$ were produced in the field, whereas in 1994, $399 \pm 63$ (S.E.) leafy spurge seeds $\mathrm{m}^{-2}$ were produced. The summer of 1994 was much drier than the summer of 1993. We estimated that 41 to 144 leafy spurge seeds were excreted daily per animal in mid-July 1993. Viability of seeds in the feces averaged $5 \%$, whereas viability of seeds collected from seed stalks was $42 \%$. We estimated that the ewes excreted from 2 to 41 leafy spurge seeds daily at the peak in mid-July 1994. Viability of seeds excreted during 1994 averaged $24 \%$, whereas viability of seeds collected from seed stalks was $68 \%$. Sheep can pick up leafy spurge seed in their fleece, and will consume and pass viable seed. However, viability of seed recovered from feces was highly variable and almost always lower than seed collected in the field. Despite reduced seed numbers and viability, sheep have the potential to spread leafy spurge and should be managed accordingly.
\end{abstract}

Key Words: weeds, feces, fleece, seed dispersal.

\footnotetext{
We thank the staff of the Montana State Seed Testing I aboratory for their help with the tetrazolium tests. We also thank J. Bouchard, S. Givens, and J. Jones for assisting with the study, and J. Lacey, K. Olson-Rutz, and R. Sheley for reviewing the manuscript. This research was funded by the USDA CSRS and by the Montana Agricultural Experiment Station. This is published with approval of the Director of the Montana Agricultural Experiment Station as Journal Series J-4063.

Manuscript accepted 1 Jan. 1996.
}

Leafy spurge (Euphorbia esula L.) is a perennial Eurasian forb that was first discovered in North America in 1827 (Selleck et al. 1962). This plant is considered noxious and currently infests over 1.1 million ha in the Northern Great Plains of the United States and Prairie Provinces of Canada (Lacey et al. 1985). Chemical control of leafy spurge is not cost-effective for most native rangelands (Lym and Messersmith 1987). Biological control with insects shows some promise, especially if it is integrated with herbicides (Lym 1994). This plant has had a major impact on the economy of North Dakota (Thompson et al. 1990).

Sheep and goats will graze leafy spurge and can be used to control infestations (Lacey et al. 1985). However, when sheep graze leafy spurge during the mature seed stage, seeds may become embedded in their fleece when seeds dehisce from capsules (Bakke 1936). Sheep also may pick up seed from the soil surface on bedgrounds. In the past, numerous plant species were introduced to Europe via sheep fleeces (Ridley 1930). Also, sheep on Utah rangelands pick up and presumably disperse capitula of squarrose knapweed [(Centaurea virgata Lam. var. squarrosa (Willd.) Boiss]; Roche and Roche 1992).

Sheep consuming leafy spurge seeds may also disperse viable seeds in their feces (Harmon and Keim 1934, Lehrer and Tisdale 1956, Özer 1979, Thill et al. 1986, Simao Neto et al. 1987, Dastgheib 1989). Viability of seed recovered from feces may be enhanced or reduced compared with seed that has not passed through sheep (Harmon and Keim 1934, Lacey et al. 1992, Wallander et al. 1995). Germinability of seeds recovered from feces generally decreases as residence time in the gastrointestinal tract of sheep increases (Özer 1979, Lacey et al. 1992, Wallander et al. 1995).

Before capsules of leafy spurge dehisce, sheep grazing infested rangeland consume seeds in capsules that may protect seed from mastication, rumination, and other digestive processes (Wallander and Olson, unpublished data). In 1 study, sheep were dosed with a known amount of mature leafy spurge seed (Lacey et al. 1992); only $18 \%$ of the seeds was recovered in their feces within 9 days. Viability of those seeds was reduced compared with unfed seed. Our objective was to determine if sheep grazing leafy spurge-infested rangeland can disperse leafy spurge seed by picking up seeds in their fleece, or by ingesting and passing viable seed in their feces.

\section{Materials and Methods}

Our study site was located in Gallatin County in southwestern Montana $\left(111^{\circ} 33^{\prime} \mathrm{W} 45^{\circ} 40^{\prime} \mathrm{N}\right)$ at 1,480 meters above sea level 
on northeast facing bluffs above the Madison River. Soils are classified as loamy skeletal mixed Aridic Calciborolls (USDA 1995). The rangeland cover type is Idahoe fescue (Festuca idahoensis Elmer)/bluebunch wheatgrass (Agropyron spicatum (Pursh) Scribn. \& Smith; Shiflet 1994). Leafy spurge cover varied from 0 to $70 \%$ on the site. Seeds of leafy spurge are roundish oval, obovate in outline and circular in cross-section, $2.0-2.5 \mathrm{~mm}$ long, 1.3 to $1.5 \mathrm{~mm}$ wide (Bakke 1936, Delorit 1970). Depending on seed color, 100 leafy spurge seeds weigh from 182 to $302 \mathrm{mg}$ (Wicks and Dercheid 1953).

At our study site, a 2.4 ha pasture was divided into 3 similar sized blocks. Each block was further divided into 2 lanes. One lane of each block was for a group of yearlings $(n=4)$ that had been exposed to leafy spurge as lambs (experienced), the other was for a group of yearlings $(n=4)$ that had not been exposed to leafy spurge as lambs (naive). All yearlings were Targhee ewes, averaging $55 \mathrm{~kg}$. Their staple length at the beginning of summer was approximately $2.5 \mathrm{~cm}$ with a fiber diameter of 22-23 microns. Each lane was divided into 3 paddocks. These ycarlings were rotated twice through these paddocks infested with leafy spurge from late May until mid-August in 1993 and 1994. From mid-August until early October 1993, a subset of yearlings were kept in a small, tame pasture that did not contain any leafy spurge before they were sheared for the fleece study.

\section{Seed in Fleece}

In October 1993, 6 of 12 naive sheep were shorn and these raw fleeces (grease) were weighed. Each fleece was tested for vegetable matter using standard methods (ASTM 1993). In this test, wool was compressed in a cylinder and 3 subsamples of 50 cores $(1.3 \mathrm{~cm}$ diameter) were removed from each fleece. Subsamples were weighed and digested in concentrated sodium hydroxide which dissolves wool fiber proteins. The remaining vegetable matter includes intact leafy spurge seed. Average number of leafy spurge seed recovered from the subsamples was multiplied by grease fleece weights to estimate the number of seeds per fleece.

\section{Seed in Feces}

As leafy spurge seed began to mature, seed densities were estimated immediately before sheep were moved into the next paddock. To determine seed densities, we walked diagonal linear transects across each paddock. A $0.25 \mathrm{~m}^{2}$ frame was placed on the soil surface every 15 paces and then all leafy spurge material within the frame that contained seed was clipped. Twenty frames within each paddock were clipped. Each sample was bagged separately and air-dried. Seeds were categorized as immature capsules (less than $1 / 2$ full size), mature capsules (full size), immature seed (yellow or yellow band), or mature seed (reddish brown up to gray and mottled; Wicks and Dercheid 1964), and then counted.

While the ewes were grazing a particular paddock, we collected 5 fresh fecal samples at least twice in each paddock, and often 3 times. Fecal samples were usually collected immediately after the ewe defecated. Seeds and capsules were readily visible in the field. Each fresh fecal sample was carefully inspected in the field, and cleaned if necessary, for capsules or seeds originating from the soil surface. Thus, we eliminated potential contamination by seed from sources other than seed ingested by the ewes. Sampling dates usually coincided with day 4,10 , and 14 after sheep entered a paddock. We repeated this sampling 3 times in 1993 and 1994.
Each fecal sample collected in 1993 was air dried, weighed, and then washed over sieves to recover leafy spurge seed. Dry weight of fecal samples ranged from 4 to $100 \mathrm{~g}$. In 1994, the entire fecal sample was weighed fresh, then a subsample was air dried and weighed to estimate moisture content. The remaining sample was washed while moist over sieves to recover leafy spurge seeds. Wet weight of manure samples collected in 1994 ranged from 6 to $249 \mathrm{~g}$. Moisture content ranged from 10 to $50 \%$.

Number of seeds per gram of feces recovered from the field was estimated and expressed on an air-dried basis. The number of seeds excreted daily per animal was estimated by multiplying seeds per gram feces by $400 \mathrm{~g}$. Mature, pregnant ewes grazing winter range defecate approximately $400 \mathrm{~g}$ dry matter daily (Soder 1993). Although pregnancy increases forage intake and fecal output, especially in the last trimester, forage intake and fecal output are lower on winter range (Soder 1993). Even though our yearlings were grazing summer range where forage intake and fecal output would be high, they were not pregnant and they were smaller than mature ewes. Based on these counteracting factors, we believe that $400 \mathrm{~g}$ is an appropriate estimate of fecal output. Polypay wethers $(51 \mathrm{~kg})$ have considerably higher fecal output (653 to $1,001 \mathrm{~g}$ dry matter per day), although these results were from confined animals consuming alfalfa pellets ad libitum (Hatfield et al. 1991).

Fecal samples were washed through 2 sieves to recover leafy spurge seed. A \#10 sieve ( $2 \mathrm{~mm}$ opening) was placed on top of a \#16 sieve (1 mm opening). Fecal samples were placed on the top sieve, rinsed with running water, and rubbed lightly to break up the sample. The \#10 sieve retained full-sized capsules whereas the \#16 sieve retained whole seeds and pieces of leafy spurge capsules. Fine organic material washed through both sieves. Dry fecal samples collected in 1993 were soaked in cold water for 4 hours before washing. Material retained by both sieves was collected, wrapped in paper towels, and dried at $37^{\circ} \mathrm{C}$ for 24 hours. After drying, samples were placed in cold storage until they could be examined for seeds. The accuracy of this procedure was tested by spiking each of 5 fecal samples with 30 mature seeds. All 30 seeds were recovered from each sample.

Percent germination of mature seed recovered from feces and collected from seed stalks was tested. Depending on the number of seeds recovered from each fecal sample, 1 to 20 seeds were placed on moist blotter paper in individual petri plates $(n=5$ plates per fecal sample). For seed collected from seedstalks, we placed 20 seeds on each of the 5 petri plates. Seeds were treated with $10 \%$ (volume) chlorine bleach solution for 10 minutes and rinsed 3 times with deionized water. These plates were placed in diffuse light in a greenhouse set at $21^{\circ} \mathrm{C}$ daytime (14 hours) and $13^{\circ} \mathrm{C}$ nighttime (10 hours) temperatures. Deionized water was added as needed. After 21 days, these plates were moist stratified at $4^{\circ} \mathrm{C}$ for 30 days in the dark. Following stratification, plates were returned to the greenhouse to test germination for 21 days. Germinated seedlings with radicles greater than $10 \mathrm{~mm}$ and open cotyledons were removed every 3-4 days. Seed that did not germinate was tested for viability using tetrazolium (Grabe 1970).

\section{Statistical Analyses}

Average leafy spurge seed production $\left(\mathrm{m}^{-2}\right)$ in each lane was estimated for 3 sampling dates in 1993 and 1994, coinciding with when the sheep were moved into a new paddock and the beginning of a fecal collection period. The number of seed excreted 
daily per animal was estimated for 7 fecal sampling dates in 1993 and 1994. Least-square means of seed production and the number of seed excreted daily per animal were dependent variables in separate models. Collection period, block, and treatment (naive or experienced) were main effects with number of mature leafy spurge seed $\mathrm{m}^{-2}$ in the field as a covariate (PROC GLM; SAS 1988). Collection dates were tested within collection periods. In a second model, percent viability was the dependent variable, and collection period, block, treatment, and class (seed recovered from feces or collected from field) were main effects. Percent viability data were transformed (arcsine squareroot) to prevent the dependence of the variance on the mean, which is inherent with data that have binomial distributions (Sokal and Rohlf 1995). We present nontransformed data in figures. Viable seed excreted daily per animal was derived by multiplying the estimated number of seed excreted daily per animal by percent viability of seed recovered from the feces that day.

\section{Results}

\section{Seed in Fleece}

On average, 38.7 leafy spurge seeds were found in each fleece (Table 1), although 3 fleeces did not contain any leafy spurge seed. Fleece weights were about $50 \%$ of normal because the ewes were shorn in October, 6 months earlier than normal.

\section{Seed in Feces}

In late June $1993,1,796 \pm 405$ (S.E.) leafy spurge seeds $\mathrm{m}^{-2}$ were produced in the field combining numbers of seeds in the different categories (Fig. 1a). Most of these seeds were in immature capsules. The proportion of mature seed collected from seedstalks increased as the summer progressed, although total number of seed decreased through the summer $(P=0.005)$. In 1994, $399 \pm$ 63 (S.E.) leafy spurge seeds $\mathrm{m}^{-2}$ were produced on 8 July (Fig. 1b). Most of the seeds were mature at this time. Total number of seed decreased through the summer $(P=0.005)$. Besides sampling later, 1994 was considerably drier than 1993 and thus the plants may have been more advanced phenologically.

1. a.

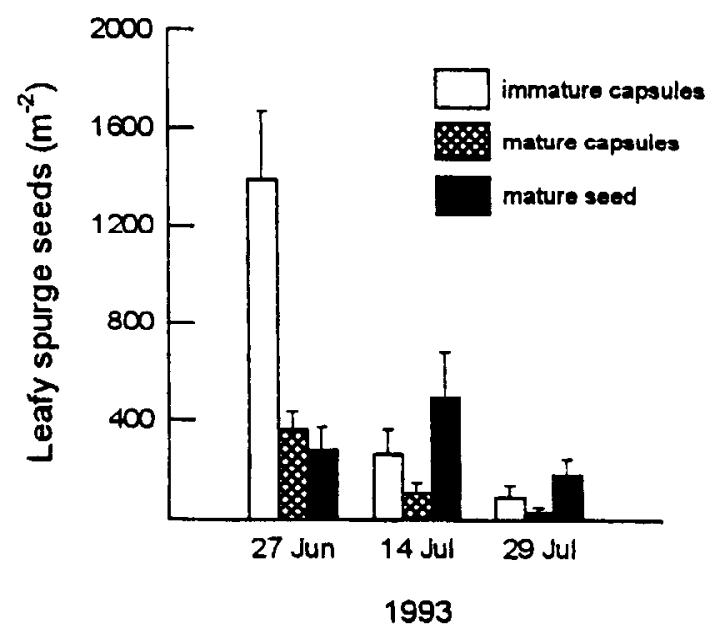

Table 1. Estimated number of leafy spurge seeds recovered from 6 fleeces in October 1993.

\begin{tabular}{ccc}
\hline \hline Sheep number & Fleece wt. & Seeds in fleece \\
\hline & $(\mathrm{kg})$ & (No.) \\
1 & 2.7 & 0 \\
2 & 2.6 & 129 \\
3 & 2.7 & 0 \\
4 & 2.7 & 29 \\
5 & 3.1 & 0 \\
6 & 2.4 & 74 \\
\hline \multicolumn{2}{c}{ mean $=38.7 \pm 21.6$ s.e. }
\end{tabular}

At the peak, 144 leafy spurge seeds were excreted daily per animal on 17 July 1993 (Fig. 2a). More seeds were excreted during this third week of July than in the other periods (period effect, $P=0.05$ ). The number of seeds excreted daily per animal was lower in 1994 than in 1993. It peaked at about 40 seeds on 11 July 1994 (period effect, P = 0.76, Fig. 2b). In 1994, the number of sceds excreted was lowest on the first sampling date shortly after they had been moved from the previous paddock, and highest 3-4 days later (collection date within period effect, $P=0.02$ ).

In 1993, viability of seed recovered from fecal samples increased after mid-July (period effect, $P=0.001$ ), yet it was always lower than seed collected from seedstalks $(P=0.0007$; Fig. 3a). In 1994, viability of seed recovered from fecal samples was lower than seed collected from seedstalks $(P=0.0002)$, but there was no trend through the summer (period effect, $P=0.26$; Fig. $3 b$ ). Overall, viability of seed recovered from feces was lower in 1993 than in 1994. Viable seed excreted daily per animal ranged between 0 and 17 in 1993 and 0 and 10 in 1994 (Fig. 4a, b).

\section{Discussion}

Sheep grazing leafy spurge infested rangeland collected seed in their fleece. However, we believe that the crimped nature of wool would result in seed readily adhering to wool fibers and becoming embedded. Unless the seed drops before it has a chance to

b.

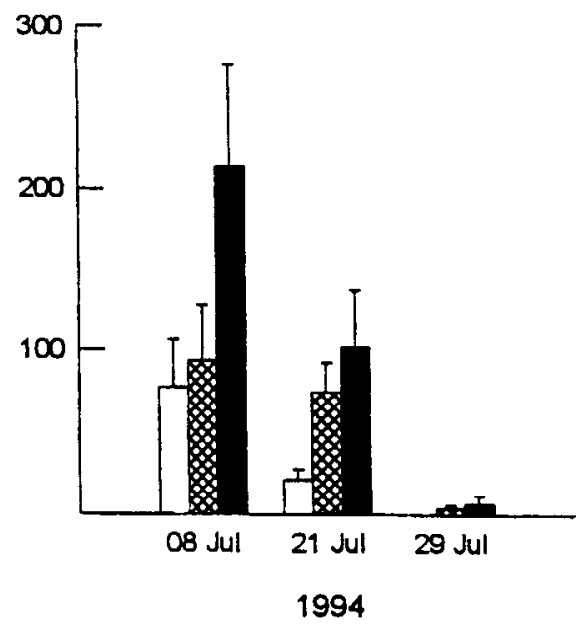

Fig. 1. Number of leafy spurge seed contained in immature capsules, mature capsules, and present as mature seed in a. 1993 and b. 1994. Sampling dates were immediately before sheep entered a new paddock. Note different scales on the y-axis for 1993 and 1994 . Error bars represent \pm 1 S.E. 
2. a.

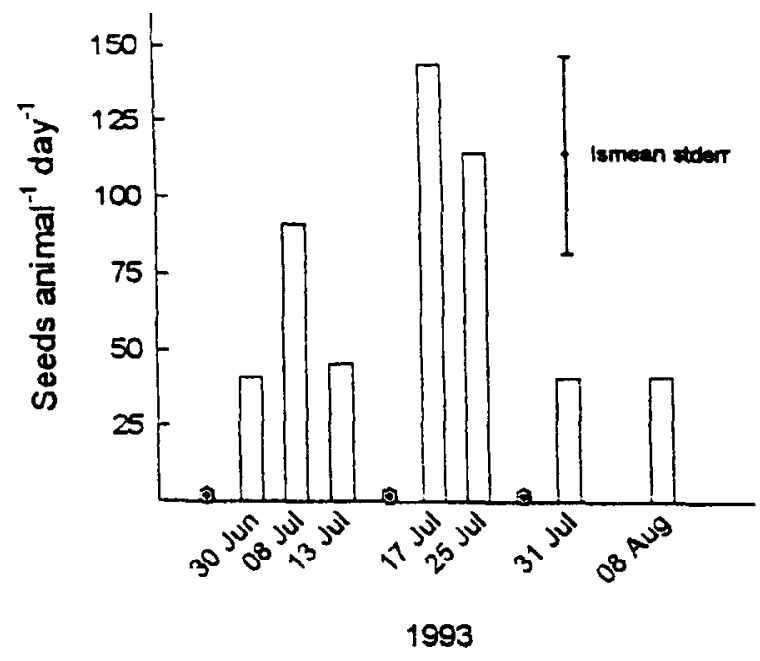

b.

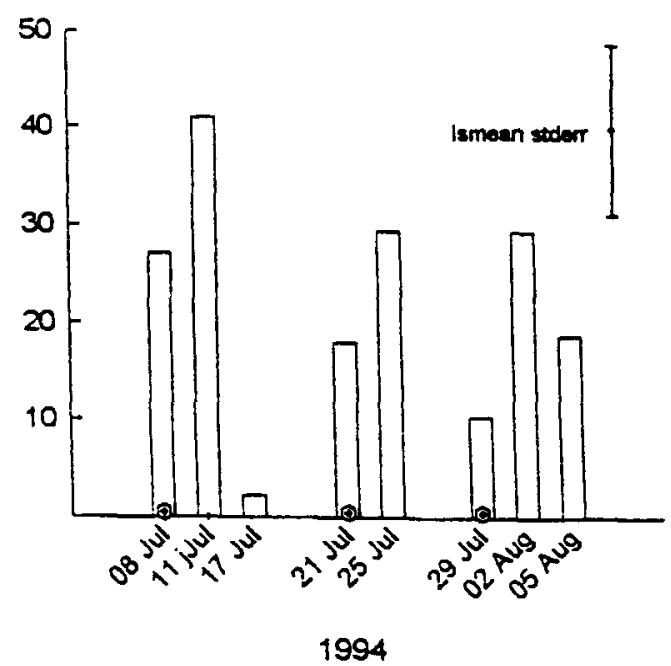

Fig. 2. Estimated number of leafy spurge seed excreted in feces of sheep in a. 1993 and b. 1994. Symbols indicate when sheep entered a new paddock. Note different scales on the y-axis for 1993 and 1994. Error bar represents \pm 1 S.E. of least square mean.

become embedded, it is unlikely that seed would be dispersed later. More likely, the seed would fall out during shearing or processing (Ridley 1930).

Seed in capsules collected from seedstalks did not germinate. When opened for the tetrazolium test, most of these seeds were empty or contained a small embryo compared with mature seed. At this early stage of seed development, sheep ingesting leafy spurge capsules have a very low potential to spread viable seed. Wicks and Dersheid (1964) found that leafy spurge seed less than 13 days old does not germinate.

More seed was excreted by ewes in 1993 than in 1994. Presumably, this is related to the greater seed production in 1993, which reflects the abnormally high precipitation during spring and summer. Surprisingly, the proportion of viable seed produced was lower in 1993 than in 1994, indicating that seed quantity and quality can be inversely related. In 1993, the seeds may not have matured fully. Besides abnormally high precipitation, temperatures were cool during the summer of 1993 and seed could have developed more slowly. On the other hand, the differences could simply reflect the differences in how fecal samples were processed. They were dried in 1993, then seed was recovered several months later by rewetting the samples. In 1994, seeds were recovered from fresh, moist feces.

The amount of seed excreted in the feces of naive and experienced sheep was similar. This indicates that these groups of sheep were consuming similar quantities of seeds. In a 3 year (1992-1994) study on grazing behavior of these same sheep, both groups spent similar amounts of time grazing leafy spurge, and
3. a.

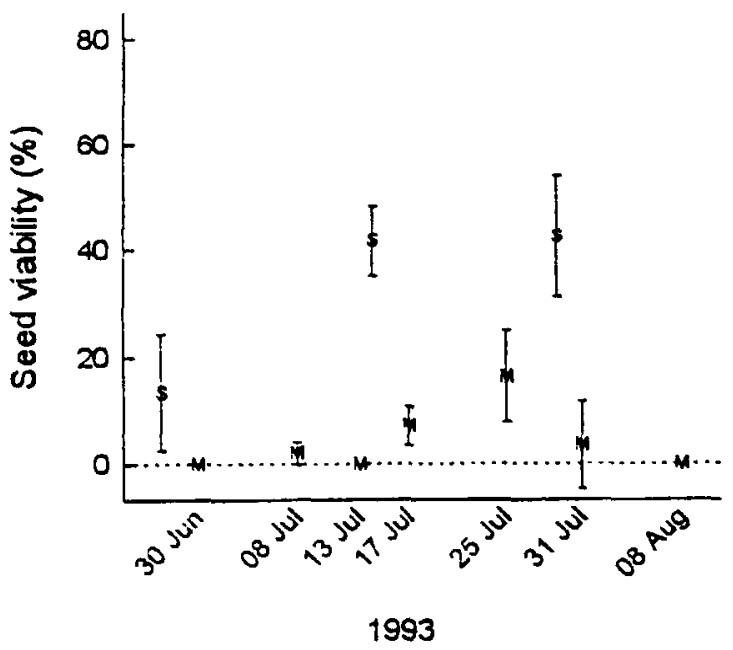

b.

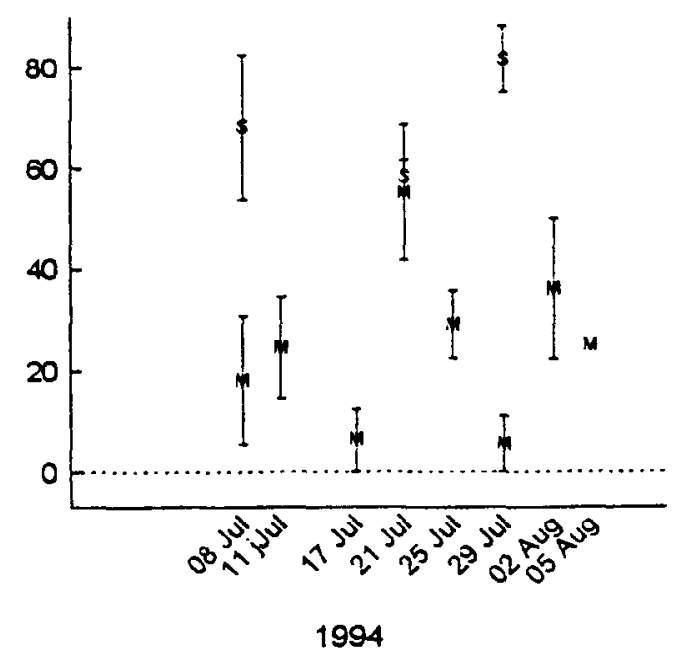

Fig. 3. Viability (\%) of leafy spurge seed excreted in feces (M), and seed collected to determine densities at the site (S) in a. 1993 and b. 1994. Error bars represent \pm 1 S.E. 
4 a.

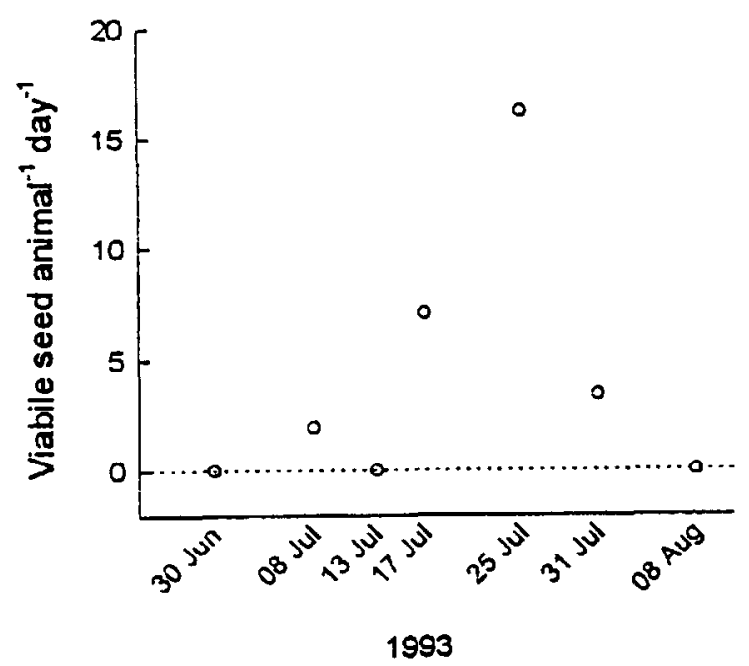

b.

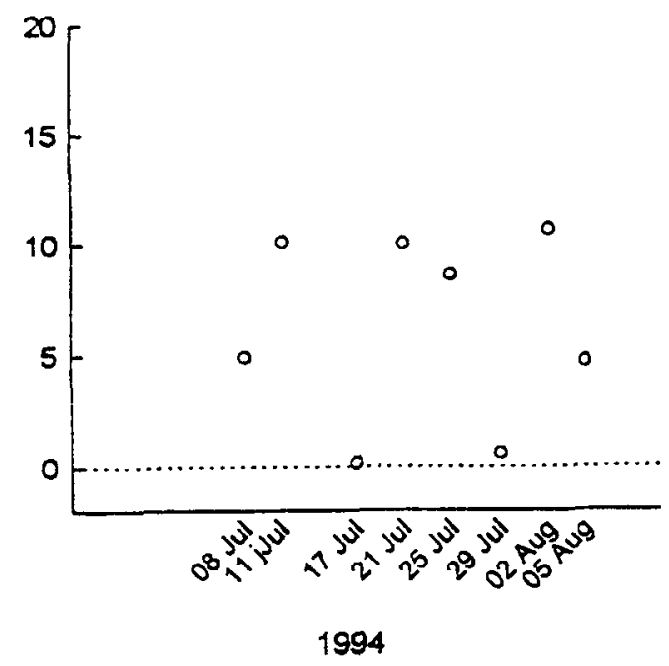

Fig. 4. Estimated number of viable leafy spurge seeds excreted daily per animal in a. 1993 and b. 1994.a

had similar biting rates of this species in mid- and late summer (Olson et al., 1996). The estimated number of seeds excreted peaked at 144 in 1993 and 40 in 1994. In another field study, about 120 seeds of another forb, Echium plantaginaum L., were excreted daily per sheep; germination of this seed was reduced by digestion (Piggin 1978). Based on a controlled dosing study, germination of leafy spurge seed is also reduced by passing through sheep and goats (Lacey et al. 1992).

In early July 1993 and the summer of 1994 , seed excreted in feces was low on the first collection date within a period, increased on the second collection date, and then was low again on the final collection date. On the first collection date, the low number could reflect that the sheep had just left a paddock in which they had removed most of the seedheads shortly after they entered that paddock. On the second collection date, high numbers of excreted seed could reflect high consumption as they entered that fresh paddock. Most seeds of leafy spurge pass through sheep within 3-4 days (Lacey et al. 1992). On the third collection date, the low number could reflect that many of the available seeds had been consumed earlier, and had already passed through the digestive tract.

During both summers, seed that passed through sheep was less viable than seed collected in the field. Passing through the gastrointestinal tract of sheep, seed is constantly exposed to a warm, moist environment including microbial and enzymatic digestion. Apparently, one or more of these factors reduces viability of leafy spurge seed. Lacey et al. (1992) found that leafy spurge seed that was pulse-dosed to sheep was not viable after 4 days residence in the gastrointestinal tract. Whereas sheep digestion reduces viability, some leafy spurge seed in feces collected in our field study was viable. For a plant considered noxious such as leafy spurge, this would be undesirable if sheep are moved from infested to noninfested areas during seed set. Even with this potential for spreading viable leafy spurge seed via feces, these seeds may not germinate readily from feces in the field. In a study that did not include leafy spurge, germination from feces was very low during a 2 year period (Karl et al. 1994).

\section{Conclusion}

Sheep grazing leafy spurge infested rangeland pick up seed in their fleece. We did not trace the path of this embedded seed, however it is unlikely that this seed will fall out on site. On the other hand, seeds that are consumed and passed through the disgestive tract may enhance the dispersal of leafy spurge. Land managers using sheep to graze leafy spurge are advised to graze leafy spurge so that it does not flower, or if it does set seed, to not move sheep from infested to noninfested areas unless the animals are confined for at least 5 days (Lacey et al. 1992).

\section{Literature Cited}

ASTM. 1993. Standard test for vegetable matter or other alkali insoluble impurities in scoured wool. D1113. Vol. .01. p. 297-301. Amer. Soc. Test. Mater. Philadelphia, Penn.

Bakke, A.L. 1936. Leafy spurge Euphorbia esula L. Iowa Agr. Exp. Sta. Res. Bull. 198.

Dastgheib, F. 1989. Relative importance of crop seed, feces and irrigation water as sources of weed infestation. Weed Res. 29:113-116.

Delorit, R.J. 1970. Illustrated taxonomy manual of weed seeds. Agron. Pub., River Falls, Wisc.

Grabe, D.F. 1970. Tetrazolium testing handbook. Contribution No. 29 to the handbook on seed testing. Assoc. Official Seed Anal. 62 p.

Harmon, G.W. and F.D. Keim. 1934. The percentage and viability of weed seeds recovered in the feces of farm animals and their longevity when buried in feces. J. Amer. Soc. Agron. 26:762-767.

Hatfield, P.G., J.W. Walker, and H.A. Glimp. 1991. Comparing the captec bolus to chromic oxide dosed twice daily using sheep in confinement. J. Range Manage. 44:408-409.

Karl, M.G., R.K. Heitschmidt, and M.R. Haferkamp. 1994. Cattle feces and plant distribution. I. Seedling emergence and establishment from a transient seed bank. Ahstract. Soc. Range Manage. Annu. Meeting. Colorado Springs, Colo.

Lacey, J.R., R.T. Wallander, and K.M. Olson-Rutz. 1992. Recovery, germinability and viability of leafy spurge (Euphorbia esula) seeds ingested by sheep and goats. Weed Tech. 6:599-602.

Lacey, C.A., P.K. Fay, R.G. Lym, C.G. Messersmith, B. Maxwell, and H.P. Alley. 1985. The distribution, biology and control of leafy spurge. Mont. Coop. Ext. Ser. Circ. 309. 16 p. 
Lehrer, W.P., Jr. and E.W. Tisdale. 1956. Effect of sheep and rabbit digestion on the viability of some range plant seeds. J. Range Manage. 9:118-122.

Lym, R.G. 1994. Ecology, economic impact, and control of leafy spurge. Proc. West. Sec. Amer. Soc. Anim. Sci. 45:111-114.

Lym, R.G. and C.G. Messersmith. 1987. Leafy spurge control and herbicide residue from annual picloram and 2,4-D application. J. Range Manage. 40:194-198.

Olson, B.E., R.T. Wallander, V.M. Thomas, and R.W. Kott. 1996. Effect of previous experience on sheep grazing leafy spurge. Appl. Anim. Behav. Sci. In Press.

Özer, Z. 1979. Ober die Beeinflussung der Keimfahigkeit de same marcher Brundlandpflanzen beam Durchgang durch den Verdauungstrakt de Schafes und nach Mistgarung. Weed Res. 19:247-254.

Piggin, C.M. 1978. Dispersal of Echium plantaginaum L. by sheep. Weed Res. 18:155-160.

Ridley, H.N. 1930. The dispersal of plants throughout the world. L. Reeve and Co., Ltd.

Roché, C. Talbott and B.F. Roche, Jr. 1992. Dispersal of squarrose knapweed (Centaurea virgata ssp. squarrosa) capitula by sheep on rangeland in Juab County, Utah. Great Basin Natur. 53:185-188.

SAS. 1988. SAS/STAT user's guide, Release 6.03 ed. SAS Institute Inc. 1028 p.
Selleck, G.W., R.T. Coupland, and C. Frankton. 1962. Leafy spurge in Saskatchewan. Ecol. Mono. 32:1-29.

Shiflet, T.N. (ed). 1994. Rangeland cover types of the United States. Soc. Range Manage., Denver, Colo.

Simao Neto, S.R.M. Jones, and D. Ratcliff. 1987. Recovery of pasture seed ingested by ruminants. 1. Seed of six tropical pasture species fed to cattle, sheep and goats. Aust. J. Exp. Agr. 27:239-246.

Soder, K.J. 1993. Influence of energy or protein supplementation on forage intake of pregnant ewes grazing Montana winter range. M.S. Thesis. Montana State Univ., Bozeman, Mont.

Sokal, R.R. and F.J. Rohlf. 1995. Biometry. Third Ed. W.H. Freeman and Co. New York.

Thill, D.C., D.L. Zamora, and D.L. Kambitsch. 1986. The germination and viability of excreted common crupina (Crupina vulgaris) achenes. Weed Sci. 34:237-241.

Thompson, F., J.A. Leitch, and F.L. Leistritz. 1990. Economic impact of leafy spurge in North Dakota. North Dakota Farm Res, 47:9-11.

U.S.D.A. 1995. Natural Resources Conservation Service. Gallatin County Soil Surv.

Wallander, R.T., B.E. Olson, and J.R. Lacey. 1995. Spotted knapweed seed viability after passing through sheep and mule deer. J. Range Manage. 48:145-149.

Wicks, G.A. and L.A. Derscheid. 1964. Leafy spurge seed maturation. Weeds 12:175-176. 